\title{
Determinants of In-stent Restenosis After Carotid Artery Stenting
}

\author{
Mehmet Eyuboglu $^{1} \cdot$ Suleyman Karakoyun $^{2} \cdot$ Ugur Kucuk $^{3}$
}

Received: 30 October 2015/Accepted: 1 December 2015/Published online: 15 December 2015

(C) Springer Science+Business Media New York and the Cardiovascular and Interventional Radiological Society of Europe (CIRSE) 2015

\section{Dear Editor,}

We read the article entitled 'The Effect of Stent Cell Geometry on Carotid Stenting Outcomes' by Alparslan et al. [1] with great interest. In their study, the investigators concluded that in-stent restenosis was more common in open-cell stent group when compared with closed-cell stent group after carotid artery stenting (CAS). We would like to emphasize some important points that may be associated with in-stent restenosis independently in patients undergoing CAS to clarify the findings of the present article.

In the Alparslan et al. study, there are no data about medical therapy that is known to essential for preventing in-stent restenosis after CAS. Treatment with optimal medical therapy including antiplatelets and statins seems to have a beneficial effect on preventing in-stent restenosis in patients undergoing CAS [2]. Also, cilostazol usage may reduce in-stent restenosis after CAS [3]. Additionally, valsartan therapy as an antihypertensive drug may prevent neointimal hyperplasia after CAS [4]. Significant differences in the treatment of optimal medical therapy may affect the in-stent restenosis rates independently. Hence, the authors should state the incidence of patients treated with optimal medical therapy including antiplatelets, statins, renin-angiotensin-aldosterone system blockers, and

Mehmet Eyuboglu

mhmtybgl@gmail.com

1 Department of Cardiology, Avrupa Medicine Center, 35170 Karabaglar, Izmir, Turkey

2 Department of Cardiology, Kars Kafkas University Medical School, Kars, Turkey

3 Department of Cardiology, Haydarpasa Training Hospital, Gulhane Military Medical Academy, Istanbul, Turkey cilostazol for each group, respectively, to define the exact role of stent type on in-stent restenosis.

In conclusion, closed-cell stents may be associated with lower rates of in-stent restenosis. However, to identify the effect of stent type on in-stent restenosis, treatment with optimal medical therapy should be taken into consideration.

\section{Compliance with Ethical Standards}

Conflict of interest We have no commercial, financial, and other relationships in any way related to the subject of this article that might create any potential conflict of interest.

\section{References}

1. Alparslan B, Nas OF, Eritmen UT, Duran S, Ozkaya G, Hakyemez B. The effect of stent cell geometry on carotid stenting outcomes. Cardiovasc Intervent Radiol. 2015. doi:10.1007/s00270-015-12113.

2. European Stroke Organisation, Tendera M, Aboyans V, Bartelink ML, Baumgartner I, Clément D, Collet JP, Cremonesi A, De Carlo M, Erbel R, Fowkes FG, Heras M, Kownator S, Minar E, Ostergren J, Poldermans D, Riambau V, Roffi M, Röther J, Sievert $\mathrm{H}$, van Sambeek M, Zeller T, ESC Committee for Practice Guidelines. ESC Guidelines on the diagnosis and treatment of peripheral artery diseases: document covering atherosclerotic disease of extracranial carotid and vertebral, mesenteric, renal, upper and lower extremity arteries: the task force on the diagnosis and treatment of peripheral artery diseases of the European Society of Cardiology (ESC). Eur Heart J. 2011;32:2851-906.

3. Miyazaki Y, Mori T, Iwata T, Aoyagi Y, Tanno Y, Kasakura S, Yoshioka K. Continuous daily use of cilostazol prevents in-stent restenosis following carotid artery stenting: serial angiographic investigation of 229 lesions. J Neurointerv Surg. 2015. doi:10. 1136/neurintsurg-2014-011565.

4. Suzuki H, Sano T, Umeda Y, Yamamoto A, Toma N, Sakaida H, Taki W. Valsartan prevents neointimal hyperplasia after carotid artery stenting by suppressing endothelial cell injuries. Neurol Res. 2015;37:35-42. 